\title{
STRUKTUR DAN DISTRIBUSI PENDAPATAN RUMAH TANGGA PENGRAJIN GULA AREN DI DESA KARANGKAMIRI KECAMATAN LANGKAPLANCAR KABUPATEN PANGANDARAN
}

\author{
STRUCTURE AND DISTRUBUTION OF HOUSEHOLD INCOME OF PALM SUGAR \\ CRAFTSMEN IN KARANGKAMIRI VILLAGE LANGKAPLANCAR DISTRICT \\ PANGANDARAN REGENCY
}

\author{
POPI PUSPITA ${ }^{1}$, TRISNA INSAN NOOR ${ }^{2}$, MUHAMAD NURDIN YUSUF ${ }^{1}$ \\ ${ }^{1}$ Fakultas Pertanian Universitas Galuh \\ ${ }^{2}$ Fakultas Pertanian Universitas Padjajaran \\ *Email: ppuspita7@gmail.com
}

\begin{abstract}
ABSTRAK
Usaha gula aren merupakan pendapatan sampingan rumah tangga di Desa Karangkamiri. Namun seringkali harga gula aren mengalami fluktuasi harga yang mengakibatkan rumah tangga harus mencari sumber pendapatan lain. Penelitian ini bertujuan untuk menganalisis: 1) Struktur pendapatan, 2) Distribusi pendapatan, dan 3) Tingkat kesejahteraan rumah tangga pengrajin gula aren di pedesaan Kabupaten Pangandaran. Metode yang digunakan adalah survey terhadap 32 orang pengrajin yang ditentukan dengan rumus Slovin pada tingkat kesalahan 15 persen dan pengambilannya dilakukan secara acak. Struktur pendapatan dihitung menggunakan analisis persentase sedangkan untuk analisis distribusi pendapatan dengan Gini Indeks serta tingkat kesejahteraan dengan BPS dalam Susenas 2011. Hasil penelitian menunjukkan bahwa: 1) Pendapatan pengrajin dari pengolahan gula aren Rp 1.640.838; pendapatan non aren Rp 464.785; off farm Rp 157.143; dan non farm $\mathrm{Rp}$ 306.250. Struktur pendapatan terbesar diperoleh dari hasil pengolahan gula aren dengan persentase sebesar $67,07 \%$ dari total pendapatan rumah tangga. 2) Nilai Gini Indeks atau Gini Rasio sebesar 0,05 artinya distribusi pendapatan pengrajin gula aren termasuk tingkat ketimpangan rendah. 3) Tingkat kesejahteraan pengrajin sebanyak $100 \%$ termasuk dalam golongan kesejahteraan tinggi.
\end{abstract}

Kata Kunci: Struktur pendapatan, struktur pengeluaran, distribusi pendapatan, tingkat kesejahteraan, rumah tangga

\begin{abstract}
Palm sugar business is a side income for households in Karangkamiri Village. However, palm sugar prices often experience price fluctuations which result in households having to look for other sources of income. This study aims to analyze: 1) income structure, 2) income distribution, and 3) the level of household welfare of palm sugar craftsmen in rural Pangandaran regency. The method used was a survey of 32 craftsmen who were determined by the Slovin formula at an error rate of 15 percent and the collection was done randomly. Income structure is calculated using percentage analysis, while for income distribution analysis using Gini Index and welfare level with BPS in Susenas 2011. The results show that: 1) The income of the craftsmen from palm sugar processing is $R p$ 1,640,838; non-aren income IDR 464,785; off farm IDR 157,143; and non-farm IDR 306,250. The largest income structure is obtained from the processing of palm sugar with a percentage of $67.07 \%$ of total household income. 2) The Gini Index or Gini Ratio value of 0.05 means that the distribution of palm sugar craftsmen's income includes a low level of inequality. 3) The level of welfare of the craftsmen is 100\% included in the high welfare category.
\end{abstract}

Keywords: Income structure, expenditure structure, income distribution, welfare level, household 


\section{PENDAHULUAN}

Rumah tangga petani merupakan unit ekonomi yang memiliki keinginan yang rasional yaitu berupaya meningkatkan kepuasan dengan jalan meningkatkan konsumsi terhadap barang dan jasa serta berupaya meningkatkan waktu santai. Menurut Bryanti (1990), rumah tangga berbeda dari unit sosial lain karena adanya tujuan yang ingin diraih untuk memenuhi kepuasan seluruh anggota rumah tangga. Disamping itu, rumah tangga memiliki karakteristik lain yang penting dalam penguasaan sumberdaya dan distribusinya antara anggota rumah tangga serta memiliki peluang melakukan pilihan cara mencapai tujuan untuk mencapai kepuasan (utilitas). Untuk meningkatkan kepuasan tersebut rumah tangga seringkali dihadapkan pada persoalan masih berkurangnya pendapatan untuk memenuhi kebutuhan rumah tangga pengrajin gula aren.

Pendapatan rumah tangga pengrajin gula aren yang rendah dan tidak memenuhi semua kebutuhan rumah tangga pengrajin, menyebabkan sebagian dari anggota rumah tangga mencari alternatif sumber pendapatan, baik dengan melakukan diversifikasi usaha gula aren maupun dengan meningkatkan alokasi curahan tenaga kerja di luar usaha gula aren yang pada akhirnya meningkatkan keragaman sumber-sumber pendapatan. Beragamnya sumber pendapatan akan berpengaruh terhadap struktur pendapatan rumah tangga pengrajin, serta akan berpengaruh terhadap distribusi pendapatan rumah tangga pengrajin. Struktur dan distribusi pendapatan akan menggambarkan tingkat kesejahteraan rumah tangga pengrajin gula aren. Dan distribusi pendapatan akan dapat menggambarkan ketimpangan pendapatan antar rumah tangga pengrajin. Semakin tinggi ketimpangan distribusi pendapatan maka semakin tidak merata pendapatan rumah tangga pengrajin yang satu dengan yang lainnya Ini sejalan dengan hasil penelitian Yusuf (2018), menunjukkan bahwa rendahnya pendapatan mendorong petani mencari sumber pendapatan lain di luar usahatani.

Penelitian ini bertujuan untuk mengkaji: 1) Struktur pendapatan rumah tangga pengrajin gula aren di Desa Karangkamiri Kecamatan Langkaplancar Kabupaten Pangandaran; 2) Distribusi pendapatan rumah tangga pengrajin gula aren di Desa Karangkamiri Kecamatan Langkaplancar Kabupaten Pangandaran; 3) Tingkat kesejahteraan rumah tangga pengrajin gula aren di Des Karangkamiri Kecamatan Langkaplancar Kabupaten Pangandaran. 


\section{METODE PENELITIAN}

Penelitian ini dilaksanakan di Desa Karangkamiri Kecamatan Langkaplancar Kabupaten Pangandaran dengan menggunakan metode survei terhadap 32 pengrajin gula aren yang diambil secara acak sederhana (simple random sampling) menggunakan rumus Slovin pada tingkat kesalahan 15 persen dari ukuran populasi sebanyak 108 pengrajin. Data yang digunakan dalam penelitian ini adalah data primer dan data sekunder.

Tujuan penelitian pertama di analisis secara deskriptif menggunakan rumus:

$$
\mathrm{P}_{\mathrm{rt}}=\mathrm{P} \text { on } \text { farm }_{\text {aren }}+\mathrm{P} \text { onfar }_{\text {non aren }}+\mathrm{P}
$$

off farm + P non farm

Dimana:

Prt $=$ Pendapatan rumah tangga petani aren perbulan

$\mathrm{P}$ on farm aren $=$ Pendapatan dari aren

$\mathrm{P}$ on farm $_{\text {non aren }}=$ Pendapatan usahatani selain gula aren

$\mathrm{P}$ off farm $=$ Pendapatan non usahatani

$\mathrm{P}$ non farm $=$ Pendapatan dari luar pertanian

Tujuan penelitian kedua di analisis secara deskriptif menggunakan rumus:

$$
\mathrm{GR}=1-\sum_{\mathrm{i}}^{\mathrm{k}} \mathrm{Fi}(\mathrm{Yi}-1+\mathrm{Yi})
$$

Dimana:

GR = Gini Ratio $(0<\mathrm{GR}<1)$
$\mathrm{Fi}=$ Persentase kumulatif penerimaan pendapatan sampai kelompok ke i

$\mathrm{Yi}=$ Persentase kumulatif pendapatan yang diterima sampai dengan kelompok ke i

$\mathrm{K}=$ Jumlah kelompok penerimaan pendapatan

$I=$ Konstanta

Berikut penilaian tinggi rendahnya ketimpangan distribusi pendapatan tersebut antara lain: (Rosyidi, 2005)

a. Indeks Gini kurang dari 0,3 menunjukkan ketimpangan distribusi pendapatanyang rendah,

b. Indeks Gini antara 0,3-0,5 menunjukkan ketimpangan distribusi pendapatan sedang,

c. Indeks Gini lebih besar atau sama dengan 0,5 menunjukkan ketimpangan distribusi pendapatan yang tinggi.

Tujuan penelitian ketiga di analisis secara deskriptif menggunakan rumus BPS dalam SUSENAS 2011 sebagai berikut:

$\mathrm{TK}=\mathrm{I} 1+\mathrm{I} 2+\mathrm{I} 3+\mathrm{I} 4+\mathrm{I} 5+\mathrm{I} 6+\mathrm{I} 7+\mathrm{I} 8+$ $\mathrm{I} 9+\mathrm{I} 10+\mathrm{I} 11$

Dimana:

$\mathrm{TK}=$ Tingkat Kesejahteraan

I1 = Pendapatan Rumah Tangga

I2 = Konsumsi/pengeluaran rumah tangga 
I3 = Keadaan tempat tinggal

I4 = Fasilitas tempat tinggal

I5 = Kesehatan anggota rumah tangga

I6 = Kemudahan mendapatkan pelayanan kesehatan

I7 = Kemudahan memasukan anak ke jenjang pendidikan

I8 = Kemudahan mendapatkan fasilitas transportasi

I9 = Kehidupan beragama

$\mathrm{I10}=$ Rasa aman dari tindakan kejahatan

I11 = Kemudahan dalam melakukan olah raga
Penentuan tingkat kesejahteraan berdasarkan skor akhir dikelompokan kedalam tiga bagian, antara lain:

1. Skor antara $27-35$ (tingkat kesejahteraan tinggi)

2. Skor antara $19-26$ (tingkat kesejahteraan sedang)

3. Skor antara $11-18$ (tingkat kesejahteraan rendah)

\section{HASIL DAN PEMBAHASAN}

Karakteristik pengrajin yang diteliti dalam penelitian ini meliputi umur, pengalaman, pendidikan, dan tanggungan keluarga

(Tabel

$1)$.

Tabel 1. Karakteristik Pengrajin Gula Aren

\begin{tabular}{|c|c|c|c|}
\hline & Uraian & Jumlah (Orang) & Persentase (\%) \\
\hline \multirow[t]{5}{*}{1} & Umur (tahun) & & \\
\hline & a. $29-41$ & 6 & 18,75 \\
\hline & b. $42-54$ & 19 & 59,37 \\
\hline & c. $55-66$ & 7 & 21,88 \\
\hline & Total & 32 & 100 \\
\hline \multirow[t]{4}{*}{2} & Pengalaman (tahun) & & \\
\hline & $8-27$ & 13 & 40,62 \\
\hline & $28-47$ & 19 & 59,38 \\
\hline & Total & 32 & 100 \\
\hline \multirow[t]{4}{*}{3} & Pendidikan & & \\
\hline & SD & 23 & 71,87 \\
\hline & SMP & 9 & 28,12 \\
\hline & Total & 32 & 100 \\
\hline \multirow[t]{4}{*}{4} & Tanggungan Keluarga (orang) & & \\
\hline & a. $1-2$ & 24 & 75 \\
\hline & b. $3-4$ & 8 & 25 \\
\hline & Total & 32 & 100 \\
\hline
\end{tabular}

Sumber: Desa Karangkamiri, 2020

Umur pengrajin gula aren berkisar antara 29 sampai 66 dengan rata-rata berumur 47 tahun sehingga berada pada rentang usia produktif. Banyaknya 
pengrajin yang berumur produktif menunjukkan bahwa potensi pengembangan usaha gula aren dinilai prospektif. Pengrajin pada golongan usia produktif ini memungkinkan mereka untuk dapat bekerja menjalankan usaha gula aren secara maksimal sehingga dapat meningkatkan pendapatannya untuk mencukupi kebutuhan.

Menurut Kartasapoetra (1991), Soekartawi (2006), dan Yunita (2011), umur merupakan salah satu faktor yang berhubungan dengan kemampuan kerja dalam melaksanakan kegiatan usahanya. Pengrajin yang berumur lebih tua biasanya cenderung bersikap sangat konservatif atau kurang responsive terhadap perubahan inovasi teknologi serta cenderung masih berpegang pada kebudayaan tradisional, sedangkan pengrajin yang berumur lebih muda cenderung memiliki semangat tinggi untuk mengetahui hal baru serta cenderung responsive terhadap perubahan.

Pengalaman usaha gula aren yang dimiliki oleh pengrajin berkisar antara 847 tahun dengan rata-rata 28 tahun. Pengalaman merupakan pengetahuan yang dikumpulkan manusia melalui penggunaan akalnya kemudian disusun menjadi bentuk yang berpola. Pengalaman seseorang dalam agroindustri berpengaruh terhadap respon dalam menerima teknologi dan inovasi baru (Soekartawi, 2006). Pengalaman yang dimiliki seseorang pada umumnya akan mempengaruhi proses pengambilan keputusan dalam menjalankan usahanya untuk mendapatkan keuntungan.

Pendidikan merupakan indikator pembangunan dan kualitas sumber daya manusia. Tingkat pendidikan yang dicapai oleh responden adalah lulusan sekolah dasar dan sekolah menengah pertama. Responden dengan pendidikan tamatan sekolah dasar lebih mendominasi, hal ini akan mengakibatkan daya serap pengrajin terhadap perkembangan teknologi menjadi lambat, sehingga terjadi kesulitan dan membutuhkan waktu yang lama untuk mengadopsi hal yang baru.

Jumlah tanggungan keluarga pengrajin berkisar 1-4 orang dengan ratarata 2 orang (keluarga kecil). Hal ini dapat diartikan bahwa jumlah tanggungan atau jumlah orang yang menjadi tanggung jawab pengrajin terhadap kelangsungan hidup juga mempengaruhi pendapatan per kapita dan pengeluaran konsumsi pangan rumah tangga (Martianto dan Ariani, 2006).

\section{Struktur Pendapatan Rumah Tangga Pengrajin Gula Aren}

Struktur pendapatan merupakan komponen penyusun pendapatan, baik 
pendapatan pokok maupun pendapatan tambahan yang diperoleh oleh seluruh anggota rumah tangga selama periode waktu tertentu. Hasil penelitian menunjukkan bahwa sumber pendapatan pengrajin cukup beragam, baik berasal dari sektor pertanian (on farm) maupun sektor non pertanian (non farm). Relatif beragamnya sumber pendapatan pengrajin gula aren ini terkait dengan kenyataan bahwa sebagai pengrajin sering kali usaha gula aren tidak mampu untuk mencukupi kebutuhan keluarganya. Hal tersebut terkait dengan produksi gula aren yang sering mengalami fluktuasi harga.

Tabel 2. Struktur Pendapatan Rumah Tangga Pengrajin Gula Aren

\begin{tabular}{lrr}
\hline \multicolumn{1}{c}{ Jenis Pendapatan } & Jumlah Pendapatan (Rp) & Kontribusi (\%) \\
\hline Usahatani Aren & 1.640 .838 & 67,07 \\
Usahatani Non-Aren & 464.785 & 19,00 \\
Luar Usahatani (Off Farm) & 157.143 & 6,42 \\
Luar Pertanian (Non Farm) & 183.594 & 7,51 \\
\hline Total & $\mathbf{2 . 4 4 6 . 3 6 0}$ & $\mathbf{1 0 0}$ \\
\hline
\end{tabular}

Sumber: Data Diolah, 2020

Pengrajin dan anggota keluarga memperoleh pendapatan dari beragam sumber, yaitu pendapatan dari usahatani aren, pendapatan usahatani padi sawah (on farm), buruh tani (off farm), serta di luar pertanian pengrajin atau anggota keluarga bekerja sebagai pedagang, supir, tukang kayu, dan sebagainya.

\section{Distribusi Pendapatan Rumah Tangga Pengrajin Gula Aren}

Pendapatan rumah tangga selain dapat diukur dari kontribusinya juga dapat dianalisis distribusi pendapatan. Distribusi pendapatan akan menggambarkan kondisi ekonomi rumah tangga pengrajin yang tercermin dari ketimpangan pendapatan rumah tangga pengrajin. Menurut Dewi (2010), ketimpangan distribusi pendapatan sering sering dikaitkan dengan kemiskinan, karena kemiskinan salah satu faktor penyebabnya ketidakmerataan distribusi pendapatan. Kemiskinan berkaitan erat dengan standar hidup absolut dari bagian masyarakat tertentu, sedangkan ketimpangan mengacu pada standar hidup relatif dari seluruh masyarakat. 
Tabel 3. Distribusi Pendapatan Rumah Tangga Pengrajin Gula Aren

\begin{tabular}{ccccrrr}
\hline No & $\begin{array}{c}\text { Kelompok } \\
\text { Pendapatan }\end{array}$ & $\begin{array}{c}\text { Pendapatan } \\
\text { Penduduk }\end{array}$ & $\begin{array}{c}\text { \% Komulatif } \\
\text { Penduduk }\end{array}$ & $\begin{array}{c}\text { Pendapatan } \\
\text { Komulatif }\end{array}$ & Yi+Yi- 1 & Fi(Yi+Yi-1) \\
\hline 1 & 40\% Terendah & 23.144 .224 & 30,67 & 30,67 & 30,67 & 0,122 \\
2 & 40\% Menengah & 31.680 .947 & 41,98 & 72,65 & 103,32 & 0,413 \\
3 & 20\% Tertinggi & 20.629 .763 & 27,34 & 100 & 203.32 & 0,406 \\
\hline \multicolumn{2}{r}{ Jumlah } & & $\mathbf{1 0 0}$ & & & $\mathbf{0 , 9 4 1}$ \\
\hline \multicolumn{2}{c}{ Gini Rasio } & & & & & $\mathbf{0 , 0 5 9}$ \\
\hline
\end{tabular}

Sumber: Data Diolah, 2020

Berdasarkan hasil penelitian ini diperoleh Indeks Gini Ratio sebesar 0,05. Angka gini ratio tersebut menunjukkan bahwa distribusi pendapatan rumah tangga pengrajin gula aren di Desa Karangkamiri berada pada tingkat ketimpangan rendah, artinya kemerataan pendapatan rumah tangga pengrajin sudah cukup baik walaupun ada beberapa pengrajin memiliki pendapatan yang lebih besar atau berbeda dengan pengrajin lainnya. Analisis ketimpangan pendapatan rumah tangga pengrajin gula aren dengan nilai gini ratio sebesar 0,05 menunjukkan bahwa distribusi tingkat pendapatan di antara masyarakat sudah cukup merata atau dengan kata lain tingkat kesenjangan dan ketimpangan rendah. Apabila nilai Indeks Gini kurang dari 0,3 menunjukkan ketimpangan distribusi pendapatan yang rendah (Rosyidi, 2005).

\section{Tingkat Kesejahteraan Rumah Tangga Pengrajin Gula Aren}

Berdasarkan hasil rekapitulasi dari indikator-indikator tingkat kesejahteraan BPS dalam Susenas 2011, maka dapat disimpulkan bahwa rumah tangga pengrajin gula aren di Desa Karangkamiri $100 \%$ termasuk dalam golongan kesejahteraan tinggi. Tingkat kesejahteraan dapat terlihat dan diukur dengan 11 indikator yang telah ditentukan dan dianggap sudah dapat mencangkup dari gambaran kesejahteraan sesungguhnya. Skor tertinggi adalah 30 dan skor terendah yaitu 28. Faktor yang paling mempengaruhi adalah faktor pendapatan dan faktor pengeluaran dan jumlah tanggungan suatu keluarga. Hasil rekapitulasi tingkat kesejahteraan pengrajin gula aren di Desa Karangkamiri tersaji dalam Tabel 4. 
Tabel 4. Tingkat Kesejahteraan Rumah Tangga Pengrajin Gula Aren

\begin{tabular}{ccccc}
\hline Kriteria & Skor & Bobot Skor & Jumlah & Persentase (\%) \\
\hline Kesejahteraan Tinggi & $27-35$ & $2,6-3,4$ & 32 & $\mathbf{1 0 0}$ \\
Kesejahteraan Sedang & $19-26$ & $1,7-2,5$ & 0 & $\mathbf{0}$ \\
Kesejahteraan Rendah & $11-18$ & $0,8-1,6$ & 0 & $\mathbf{0}$
\end{tabular}

Sumber: Data Diolah, 2020

\section{KESIMPULAN DAN SARAN}

\section{Kesimpulan}

1. Struktur pendapatan rumah tangga pengrajin gula aren di Desa Karangkamiri terdiri dari pendapatan usahatani aren, pendapatan non-aren, pendapatan off farm dan pendapatan non farm. Pendapatan rumah tangga pengrajin yang berasal dari usaha pengolahan aren memberikan kontribusi terbesar $(67,07 \%)$ dibandingkan pendapatan non-aren $(19,00 \%)$, pendapatan off farm $(6,42 \%)$ dan pendapatan non farm $(7,51 \%)$.

2. Distribusi pendapatan rumah tangga pengrajin gula aren di Desa Karangkamiri berada pada ketimpangan rendah, dengan indeks Gini Rasio sebesar 0,05 ini berarti pendapatan diantara rumah tangga pengrajin gula aren di Desa Karangkamiri relatif merata.

3. Berdasarkan kriteria 11 indikator kesejahteraan dari BPS dalam Susenas 2011 menunjukkan 100\% rumah tangga pengrajin gula aren di Desa Karangkamiri termasuk dalam golongan kesejahteraan tinggi.

\section{Saran}

Bagi pemerintah setempat baik aparatur Desa atau Kecamatan untuk lebih memperhatikan pertanian khususnya pengolahan aren karena memiliki potensi yang cukup besar untuk meningkatkan perekonomian masyarakat Desa Karangkamiri khususnya pengrajin gula aren. Hal tersebut dapat dilakukan dengan menghidupkan peran kelompok tani, sehingga koordinasi antara program pemerintah dan keadaan di lapangan dapat berjalan dengan baik.

\section{DAFTAR PUSTAKA}

Bryanti, W.K. 1990. The Economic Organization of the Household. Cambridge University Press. Cambride.

Yusuf, M.N, Lies S, Tuhwapana P.S dan Nono C. 2017. Struktur Pendapatan dan Pengeluaran Rumah Tangga Petani Padi Sawah di Daerah Rawan Banjir Kabupaten Pangandaran. 
Fakultas Pertanian Universitas Galuh dan Universitas Padjajaran.

Rosyidi, S. 2005. Pengantar Teori Ekonomi: Pendekatan Kepada Teori Ekonomi Mikro dan Makro. Jakarta: PT. Raja Grafindo Persada.

Badan Pusat Statistik. 2007. Indikator Kesejahteraan Rakyat Indonesia. Badan Pusat Statistik. Jakarta.

Badan Pusat Statistik. 2011. Survey Sosial Ekonomi Nasional 2011. Jakarta.

Kartasapoetra, A.G. 1991. Teknologi Penyuluhan Pertanian. Jakarta: Bina Aksara.

Soekartawi. 2006. Analisis usahatani. Jakarta: UI Press.
Yunita. 2011. Strategi Peningkatan Kapasitas Petani Padi Sawah Lebak menuju Ketahanan Pangan Rumah Tangga di Kabupaten Ogan Ilir Provinsi Sumatera Selatan. Disertasi. Institut Pertanian Bogor: Bogor.

Martianto, D. Ariani, M. 2006. Penilaian situasi pangan dan gizi di wilayah kerja plan Indonesia program unit lembata. Kerjasama Fakultas Ekologi IPB dengan Plan Indonesia.

Dewi, N. 2010. Dampak Pengembangan Perkebunan Kakao Rakyat Melalui P2WK Terhadap Distribusi Pendapatan di Kabupaten Donggala Sulawesi Tengah. Jurnal Agroland 17(3): 219-225. Sulawesi Tengah. 